\title{
Morpho-physiological characteristics by sweet potato cultivars as function of irrigation depth
}

\author{
FÁBIO T. DELAZARI ${ }^{1}$, IGOR R. ASSIS ${ }^{2}$, DIEGO F.V. CABRERA ${ }^{1}$, MARIANE G. FERREIRA ${ }^{1}$, \\ LUIZ E. DIAS ${ }^{2}$, ANGELICA RUEDA ${ }^{1}$, JOSÉ C. ZANUNCIO ${ }^{3}$ and DERLY J.H. SILVA ${ }^{1}$ \\ ${ }^{1}$ Universidade Federal de Viçosa, Centro de Ciências Agrárias, Departamento de Fitotecnia, \\ Avenida P.H. Rolfs, s/n, Campus Universitário, 36570-900 Viçosa, MG, Brazil \\ ${ }^{2}$ Universidade Federal de Viçosa, Centro de Ciências Agrárias, Departamento de Solos, \\ Avenida P.H. Rolfs, s/n, Campus Universitário, 36570-900 Viçosa, MG, Brazil \\ ${ }^{3}$ Universidade Federal de Viçosa, Centro de Ciências Agrárias, Departamento de Entomologia, \\ Avenida P.H. Rolfs, s/n, Campus Universitário, 36570-900 Viçosa, MG, Brazil
}

Manuscript received on September 4, 2017; accepted for publication on April 9, 2018

\begin{abstract}
The sweet potato is an alternative energy source, but its sustainability depends on efficient water use. The objective of this study was to evaluate sweet potato morpho-physiological characteristics, and water use efficiency (WUE). Irrigation depths of 50, 75, 100, and 125\% of crop evapotranspiration (ETc) were applied. The morpho-physiological indicators, WUE, leaf area index (LAI), leaf water potential, leaf temperature, and leaf chlorophyll index (ICF), were evaluated. The WUE of the sweet potato cultivars increased until the $75 \%$ water depth of the ETc. The LAI of these cultivars increased with irrigation depth, with higher values at $100 \%$ of the ETc. The leaf water potential of the two sweet potato cultivars was lowest with the lower irrigation depth. Leaf temperature was closer to that of ambient temperatures in treatments with greater irrigation depth. The increase of the WUE with the greater accumulation of dry biomass is due to greater $\mathrm{CO}_{2}$ diffusion by stomata. The reduction in the growth of these plants is due to water stress limiting stomatal conductance, transpiration, leaf growth (LAI) and chlorophyll concentration, proportional to soil moisture conditions. The functional relationship between soil moisture and growth is essential to optimize irrigation management at different growth stages.
\end{abstract}

Key words: Ipomoea batatas, irrigation management, leaf temperature, water stress, water use efficiency.

\section{INTRODUCTION}

Increased drought around the world, in a scenario of global climate change, may reduce growth, development, and agricultural productivity. Water scarcity causes abiotic stresses such as drought and salinity, affecting metabolic, physiological,

Correspondence to: Fábio Teixeira Delazari

E-mail: fabio.delazari@ufv.br and biochemical plant functions (Jaleel et al. 2009, Ierna and Mauromicale 2012).

Water stress can vary among plants, and soil moisture conditions should be taken into account for maintaining growth and agricultural productivity (Jaleel et al. 2009, Doupis et al. 2013).

Leaf temperature of plants under water stress is higher than those with adequate water availability. This parameter is used to assess indirectly the 
effects of water availability, as the optimal stomata conductance is observed with a leaf temperature between 25 and $30{ }^{\circ} \mathrm{C}$ (Machado et al. 2005, Testi et al. 2008).

The sweet potato, Ipomoea batatas (L.) Lam. (Convolvulaceae), is the seventh most cultivated crop in the world, but its use as food is marginal in industrialized countries (Montefusco et al. 2014).

Starch represents $17.5 \%$ of the fresh weight and $40-50 \%$ of that of dry I. batatas tubers. Further, this plant is, per hectare, more productive than wheat (Duvernay et al. 2013). However, climate change and extreme rainfall and drought can affect productivity of this plant (Singh and Reddy 2011, Lee et al. 2012, Duvernay et al. 2013).

Climate change can affect the leaf area index (LAI), which depends on spatial leaf organization such as vegetation density, horizontal and vertical leaf distribution, and leaf insertion angle. The photosynthates produced by short-cycle plants increase with the IAF, but the absorption of light energy increases indefinitely along with this parameter, being limited by self-shading from the upper leaves (Posada et al. 2012).

The objective of this study was to evaluate morphological (leaf area index) and physiological (leaf temperature, leaf water potential and leaf chlorophyll index) indicators of two sweet potato cultivars with increasing irrigation levels.

\section{MATERIALS AND METHODS}

\section{EXPERIMENTAL AREA}

The experiment was conducted in a greenhouse at the Experimental Area of the Irrigation and Drainage Department of Agricultural Engineering of the Universidade Federal de Viçosa in Viçosa, Minas Gerais state, Brazil (latitude $20^{\circ} 45^{\prime} \mathrm{S}$, longitude $42^{\circ} 52^{\prime} \mathrm{W}$ and altitude $648 \mathrm{~m}$ ).

The soil in the experimental area was classified as clayey, presenting average organic matter content equal to $2.4 \mathrm{dag} / \mathrm{kg}$. The average bulk density was $1.30 \mathrm{~g} \mathrm{~cm}^{-3}$ and the moisture for the field capacity and wilting point were 0.384 and $0.218 \mathrm{~m}^{3} \mathrm{~m}^{-3}$, respectively. The soil preparation for planting was carried out with rotary tiller, followed by manual formation of ridges spaced 1.0 m. The soil chemical analysis carried out prior to planting showed that it is eutrophic, with $\mathrm{pH}$ of 6.1; available $\mathrm{P}$ and $\mathrm{K}$ levels of 58.1 and $557.0 \mathrm{mg} \mathrm{dm}$ ${ }^{3}$, respectively; exchangeable contents of $\mathrm{Ca}^{2+}$ and $\mathrm{Mg}^{2+}$ equal to 3.7 and $1.2 \mathrm{cmol}_{\mathrm{c}} \mathrm{dm}^{-3}$, respectively; and base saturation of $75.2 \%$. According to these characteristics, acidity correction and fertilization practices with phosphate and potassium are not necessary. Nitrogen fertilization was carried out with the amount of $200 \mathrm{~kg} \mathrm{ha}^{-1}$ of $\mathrm{N}$ (Ribeiro et al. 1999). Divided into two applications at 30 and 60 days after planting, with ammonium sulfate.

\section{CULTIVARS}

The sweet potato cultivars Amanda and Duda were obtained from the breeding program of the Federal University of Tocantins. The spacing used was 0.25 $\mathrm{m}$ between plants and $1.0 \mathrm{~m}$ between planting lines.

\section{IRRIGATION MANAGEMENT}

The crop was irrigated with a dripper spaced at $0.3 \mathrm{~m}$, each one having an actual flow of $1.71 \mathrm{~L}$ $\mathrm{h}^{-1}$. The system presented Christians Uniformity Coefficient (CUC) of $94 \%$ and application intensity of $5.70 \mathrm{~mm} \mathrm{~h}^{-1}$. Irrigation depth treatments were based on sweet potato evapotranspiration (ETc). The frequency of wetting was every two to three days with water demand calculated by estimating the evapotranspiration for this culture (ETc).

The equations used to estimate the sweet potato evapotranspiration were; ETc $=$ ETo $\mathrm{x}$ Kc Eq.1 and Eq. $2 \mathrm{Kc}=(\mathrm{Kcb} \times \mathrm{Ks})+\mathrm{Ke}$ where ETc is the crop evapotranspiration $\left(\mathrm{mm} \mathrm{d}^{-1}\right)$; EToevapotranspiration reference $\left(\mathrm{mm} \mathrm{d}^{-1}\right)$; Kc, adimensional coefficient of the culture; Kcb, basal adimensional coefficient of the culture; Ke, adimensional soil evaporation 
coefficient; and $\mathrm{Ks}$, the adimensional stress ratio (Allen et al. 2006, Angeli et al. 2016). The initial, intermediate, and final $\mathrm{Kcb}$ values, (respectively $0.15 ; 1.10$ and 0.55 ), were used in the calculations (Allen et al. 2006). The sweet potato cycle was divided into four phenological stages, based on plant growth periods according to area shadedper plant, each one having a different value for the crop coefficient $(\mathrm{Kc})$. The first stage began with seedling transplantation until $10 \%$ of the area was shaded, around 20 days. The second stage lasted 40 days and finished when approximately $80 \%$ of the area was covered by the culture. The third stage began with $80 \%$ of the area shaded until the harvesting period, when the average tuberous root weight was approximately $300 \mathrm{~g}$ with 110 and 136 days for the Amanda and Duda cultivars, respectively. The last stage occurred 20 days before harvesting (Allen et al. 2006).

\section{EXPERIMENTAL DESIGN}

The experiment was conducted in a randomized block design with four irrigation depths, 50, 75, 100, and $125 \%$ of the ETc, representing the treatments with four replications (Table I). Ninety-six lines, $4.5 \mathrm{~m}$ long with a total cultivated area of $432 \mathrm{~m}^{2}$ were used, considering the rows to be borders. The central plants were evaluated for the treatments. The plots had a total area of $13.5 \mathrm{~m}^{2}$ with three $4.5 \mathrm{~m}$ lines with 54 plants. The central line had 14 plants per plot with a $3.5 \mathrm{~m}^{2}$ area evaluated.

\section{MORPHOLOGICAL INDICATORS EVALUATED}

The leaf area index was determined in six readings using the LAI-2000 (LI-COR), one above the canopy and five below.

The leaf water potential was determined using a Scholander pump pressure chamber. Four sweet potato leaves were collected per experimental unit, at the same physiological maturity stage in the middle portion of the branch between 4:30 and 6:00pm. Water potential was determined with a leaf positioned upside down, with its petiole exposed on a drum in a pressure chamber. The petiole was cut and sealed in the pressure chamber. Nitrogen gas was introduced to attain the necessary pressure to exude a thin film of sap from the cut portion of the petiole. This was measured with a pressure gauge and the value recorded corresponding to its pressure (Scholander et al. 1965). Leaf temperature was measured using an infrared thermometer 30 $\mathrm{cm}$ from the leaf, with readings taken starting from $12: 00 \mathrm{pm}$ at 30 minute intervals. Four readings were taken randomly per experimental unit on clear, cloudless days. Air temperature was measured at the weather station in the experiment area to determine the difference between canopy and ambient values.

The chlorophyll content was obtained in three measurements with a portable electronic ClorofiLOG meter (CFL 1030, Falker) from four healthy plants.

Efficiency of water use (USA) at the end of the phenological cycle was derived using the production ratio $(\mathrm{P})$ and water volume applied $(\mathrm{V})$ $\left(\mathrm{kg} \mathrm{m}^{-3}\right)$ with: US $=\mathrm{P} / \mathrm{V}$, where US is water use efficiency $\left(\mathrm{kg} \mathrm{m}^{-3}\right)$; $\mathrm{P}$, production (kilograms); and $\mathrm{V}$, water volume applied $\left(\mathrm{m}^{3}\right)$ (Caliman et al. 2010, Mantovani et al. 2013).

The leaf temperature was measured with an infrared thermometer about $30 \mathrm{~cm}$ from the leaf with readings starting at $12: 00 \mathrm{pm}$ at 30 minute

TABLE I

Treatments, percentage depth and irrigation depth for sweet potato cultivars Amanda and Duda

\begin{tabular}{cccc}
\hline \multirow{2}{*}{ Treatment } & $\begin{array}{c}\text { Percentage } \\
\text { depth } \\
\text { (\% ETc) }\end{array}$ & \multicolumn{2}{c}{ Irrigation depth (mm) } \\
\cline { 3 - 4 } & 50 & Amanda & Duda \\
\hline T1 & 75 & 217.8 & 246.4 \\
T2 & 100 & 345.7 & 375.9 \\
T3 & 125 & 409.6 & 440.6 \\
T4 & & & \\
\hline
\end{tabular}


intervals. Four readings were taken randomly per experimental unit on cloudless days. The air temperature was measured at the weather station in the experiment area to determine the difference between canopy and the ambient temperatures.

The results were subjected to variance analysis, and the effect of water depth to regression analysis, using the statistical program R (R Development Core Team 2014).

\section{RESULTS}

The WUE of the sweet potato cultivars Amanda and Duda increased up to $75 \%$ of the ETc., with 16 $\mathrm{kg} \mathrm{m}^{-3}$ to $20 \mathrm{~kg} \mathrm{~m}^{3}$ with those of 300 and $330 \mathrm{~mm}$, respectively. These values were 9.8 and $10.7 \mathrm{~kg} . \mathrm{m}^{-}$ ${ }^{3}$, respectively, with the lower irrigation depth (218 and $246 \mathrm{~mm}$ ) equivalent to $50 \%$ ETc (Figure 1a).

The leaf water potential of the Amanda and Duda cultivars was lower with the lower water depth and increased exponentially with the irrigation depths (Figure 1b).

The LAI were lower with the irrigation depth of 218 and $246 \mathrm{~mm}$ (50\% ETc.), 1.8 and $2.1 \mathrm{~m}^{2} \mathrm{~m}^{-2}$ for the Amanda and Duda cultivars, respectively. The maximum LAI value, 3.4 and $3.9 \mathrm{~m}^{2} \mathrm{~m}^{-2}$ were observed with a water depth of 353 and $385 \mathrm{~mm}$ (100\% ETc). The maximum water depth, 410 to $441 \mathrm{~mm}(125 \% \mathrm{ETc})$, reduced the LAI for both cultivars (Figure 2a).

Both cultivars have higher ICF values with $100 \%$ ETc and negative responses as a function of irrigation depth (Figure 2b).

The temperature of $32.6{ }^{\circ} \mathrm{C}$ and 31.9 for the Amanda and 32.1 and $31.6{ }^{\circ} \mathrm{C}$ for the Duda cultivar, with the larger irrigation depth (100 and $125 \%$ ETc) was closest to the ambient temperature (Figure 3). Plant temperatures with smaller irrigation depths were higher than the ambient temperature, 2.9 up to $3.3{ }^{\circ} \mathrm{C}$ for the Amanda and Duda cultivars, respectively.

\section{DISCUSSION}

The increase in the WUE up to $75 \%$ of the ETc water depth, $16 \mathrm{~kg}$ to $20 \mathrm{~kg} \mathrm{~m}^{-3}$ to $300 \mathrm{~m}^{3}$ and 330 $\mathrm{mm}$ without water deficiency (Figure 1a), resulted in a higher accumulation of dry matter what was explained by the greater $\mathrm{CO}_{2}$ diffusion through stomata, which remain open longer in these conditions (Bergantin et al. 2004, El-Sharkawy and De Tafur 2010). Sub-optimal water depth causes water stress, and limits plant growth, mainly due to reductions in carbon balance, the production of which depends on photosynthesis (Lawlor and Cornic 2002, Flexas et al. 2009). Plants under drought conditions have a lower photosynthetsis rate (Yooyongwech et al. 2013), reducing energy and metabolite availability for growth and optimal crop production (Kulkarni and Phalke 2009). WUE values of 9.8 and $10.7 \mathrm{~kg} \mathrm{~m}^{-3}$ for the Duda and Amanda cultivars with 218 and $246 \mathrm{~mm}$ water depths ( $50 \%$ of Etc), respectively, can be explained by early closing of stomata in response to water deficits. This reduces water loss from transpiration, and through internal storage, due to the $\mathrm{CO}_{2}$ and $\mathrm{H}_{2} \mathrm{O}$ diffusion and the photosynthetic rate (Chaves et al. 2009).

The negative water potential of the potato leaf, more pronounced for the Duda cultivar (Figure 1b), shows that responses to this parameter depend on plant variety, soil, water availability, registration time with changes in stomatal conductance, and transpiration rate (Nogueira et al. 2000, Sato et al. 2004). Plants can be evaluated for their leaf water potential correlated to gas exchange, growth, and physiological parameters (Williams and Araújo 2002). The leaf water potential increased exponentially with increasing water availability in the soil. On the other hand, the linear increase in the leaf water potential was observed for the potato culture (Gajanayake et al. 2014). The reduction of water potential may induce osmotic adjustments in plants to promote leaf hydration and the production 


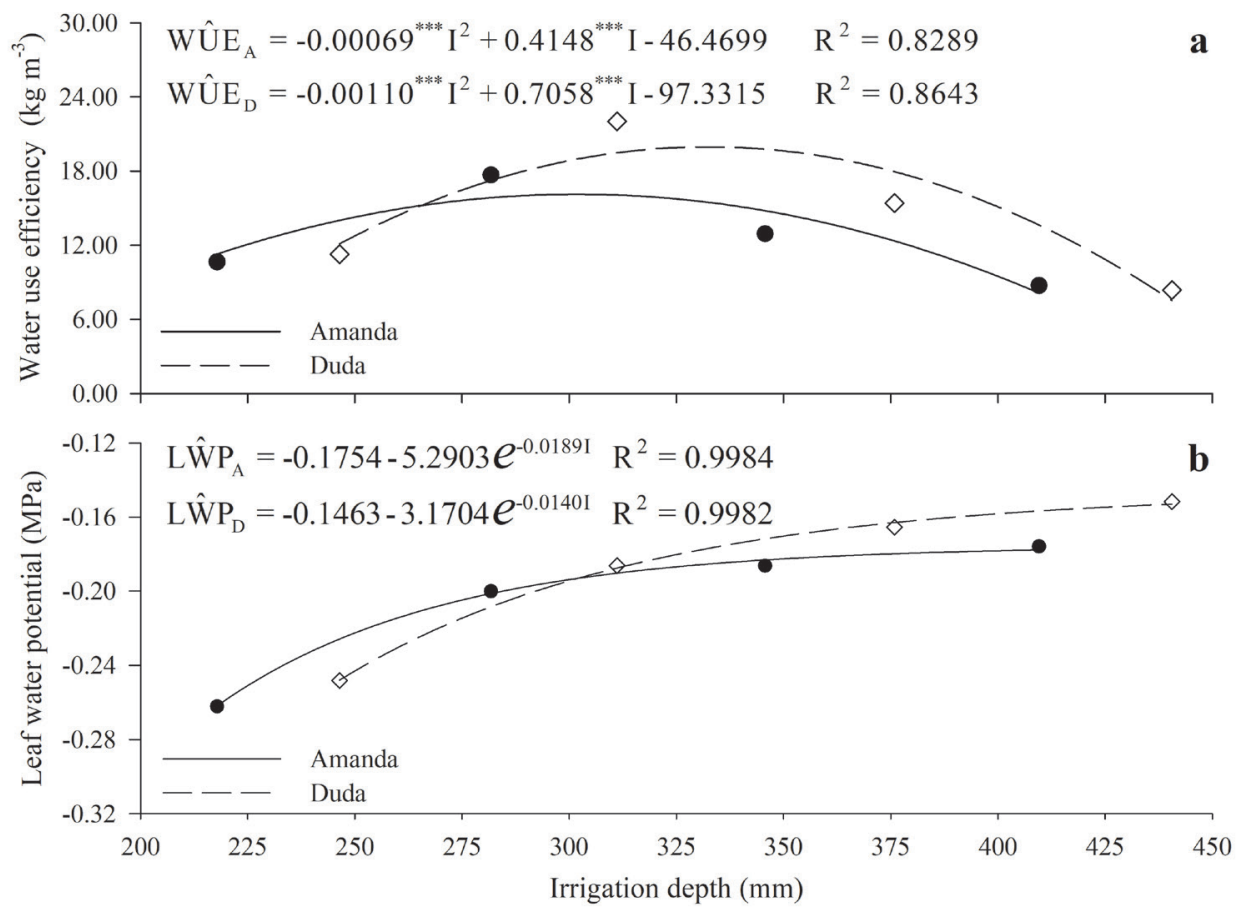

Figure 1 - Efficiency in water use $\left(\mathrm{kg} \mathrm{m}^{-3}\right)$ (a) and leaf water potential (MPa) (b) of Amanda and Duda cultivars depending on irrigation depth. ***Significant at the $1 \%$ level of likely by the " $\mathrm{t}$ " test.

of hormones to adapt to this condition (Abdel 2014). The combination of water stress and hormonal metabolism in the Duda cultivar is possibly more efficient due to its adaption to adverse conditions. However, responses to favorable conditions may otherwise influence crop yields (Abdel 2014). Roots absorb water via the water potential gradient between soil and roots. For this reason, plants face greater difficulty to extract water from soil with low water concentrations insufficient to balance losses from transpiration (Siddique et al. 2000).

The lower LAI, for the Amanda and Duda cultivars (Figure 2a), with 218 and $246 \mathrm{~mm}$ (50\% ETc) irrigation depth is due to reduced domestic stomate conductance due to soil moisture deficiencies (Warren 2008). The lower respiratory rate is due to leaf expansion and ultimately leaf area index (Liu and Stützel 2002), allowing plants to survive with low water absorption rates by controlling transpiration (Gajanayake et al. 2014). This reduces water loss by decreasing leaf area and stomate conductance, thereby avoiding leaf tissue dehydration (Liu and Stützel 2004). The maximum LAI, 3.4 and $3.9 \mathrm{~m}^{2} \mathrm{~m}^{-2}$, with 353 and $385 \mathrm{~mm}$ (100\% etc.) irrigation depths for the Amanda and Duda cultivars respectively, is similar to that of cassava cultivars, 3.98 and $3.59 \mathrm{~m}^{2} \mathrm{~m}^{-2}$, from January to March, respectively, and 3 to 4 $\mathrm{m}^{2} \mathrm{~m}^{-2}$ in the tuber initiation stage, suitable for the vegetative growth of this plant (Lopes et al. 2010). Plants with continuous irrigation are more resistant to water deficits in the soil than those gradually undergoing water stress at the beginning of the cycle (Santos and Carlesso 1998). This explains the greater variation of the LAI of Amanda and Duda cultivars with higher water depth, 3.4 and $3.9 \mathrm{~m}^{2} \mathrm{~m}^{-2}$ compared to plants experiencing low soil moisture conditions, 1.8 and $2.1 \mathrm{~m}^{2} \mathrm{~m}^{-2}$, respectively.

Negative ICF responses of Amanda and Duda cultivars to water depths (Figure 2b), reinforce the fact that soil moisture conditions proportionally determine the total concentration of chlorophyll produced (Farooq et al. 2009, Gajanayake et al. 2014) from enzymatic break down of this material 


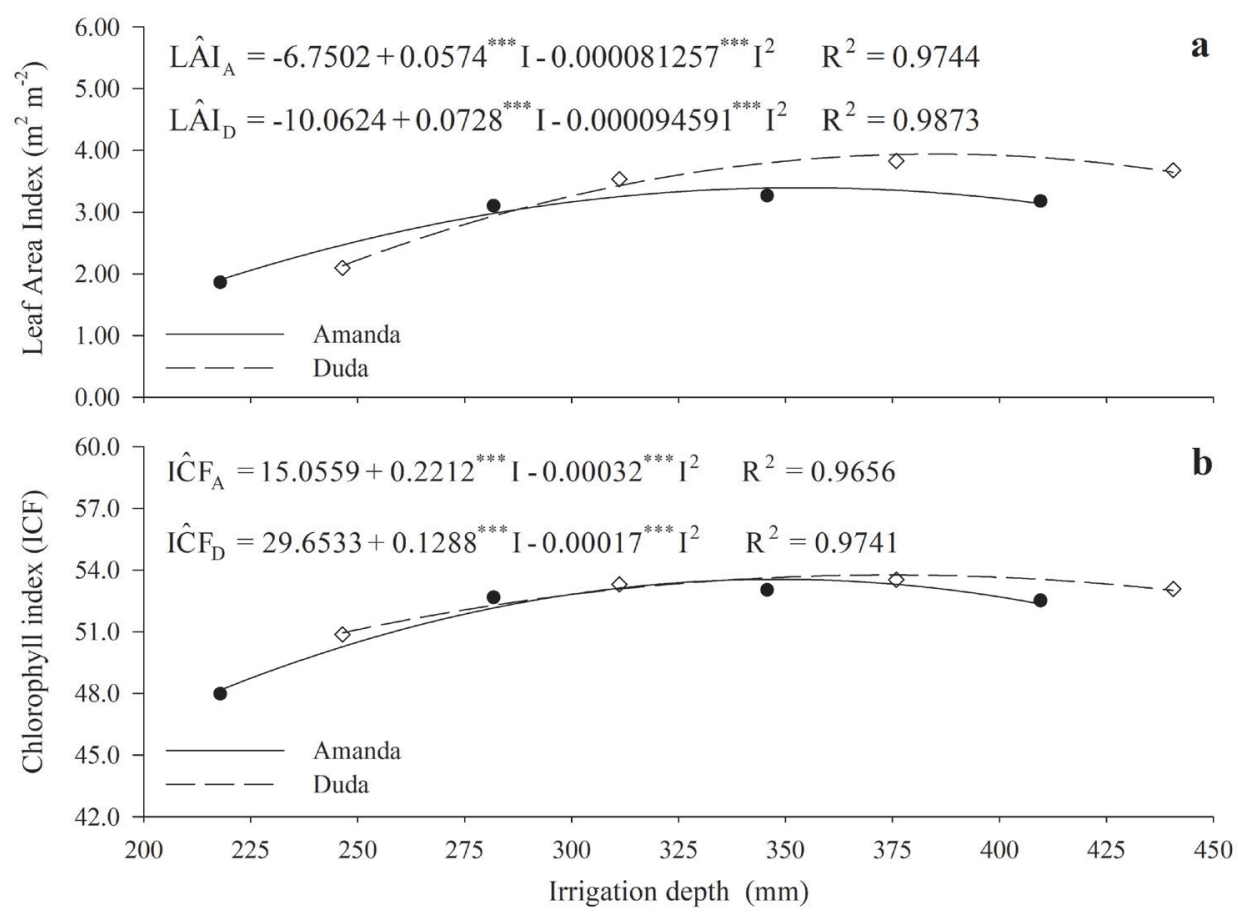

Figure 2 - Leaf area index $\left(\mathrm{m}^{2} \mathrm{~m}^{-2}\right)$ (a) and chlorophyll index (ICF) (b) of Amanda and Duda cultivars depending on irrigation depth.*** Significant at the $1 \%$ level of the "t" test. **** Significant at the level of 1 to $5 \%$, by "t" test.
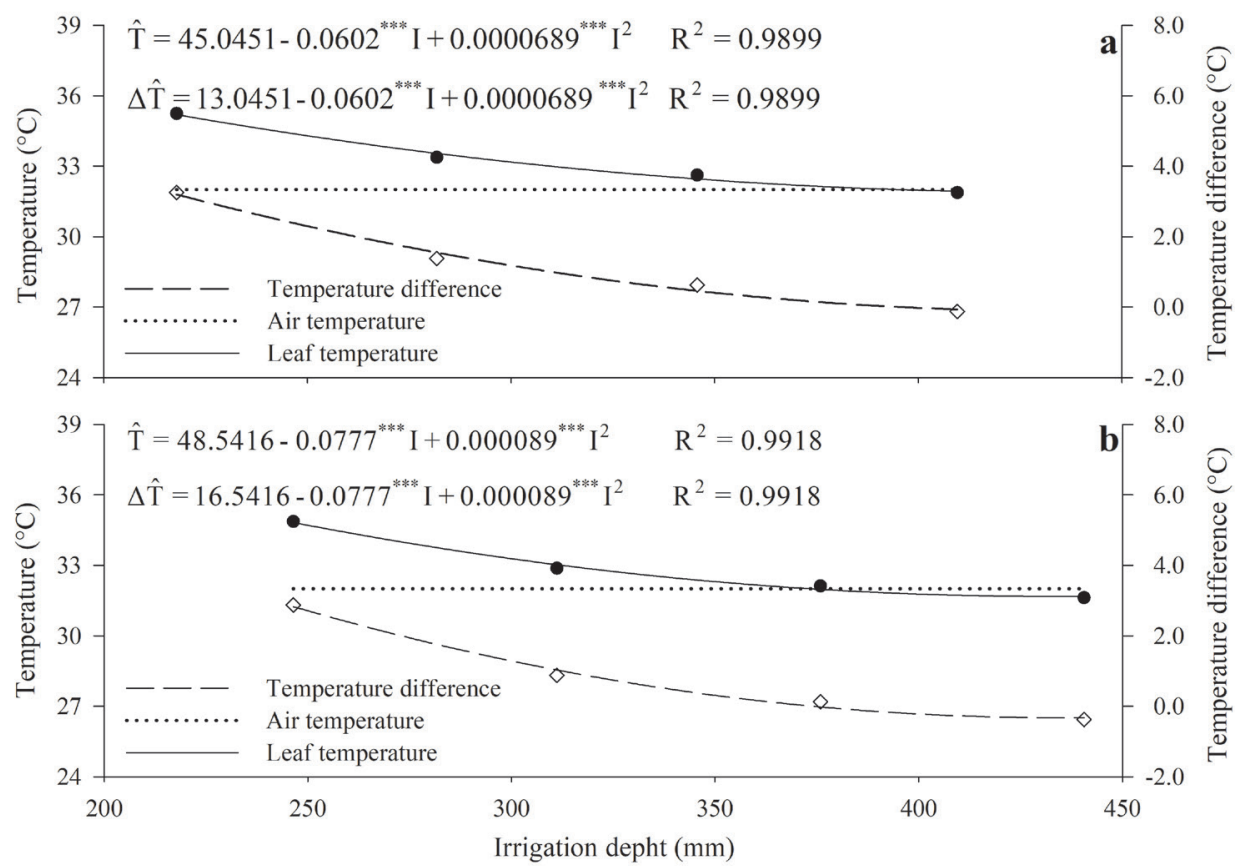

Figure 3 - Air temperature, leaf temperature $\left({ }^{\circ} \mathrm{C}\right)$ and the temperature difference $\left({ }^{\circ} \mathrm{C}\right)$ between the canopy and the air as a function of applied irrigation depht in the cycle of sweet potato cultivars Amanda (a) and Duda (b). *** Significant at the $1 \%$ level of the test " $t$ ". 
(Gholami et al. 2012). The impact of drought on stomatal conductancehampers plantmetabolism and chlorophyll concentration (Warren 2008), reducing the photosynthetic capacity, productivity, and starch accumulation, with a negative effect on chlorophyll stability in sweet potato cultivars (Songsri et al. 2008, Gonçalves et al. 2010, Jangpromma et al. 2010). The higher chlorophyll content in the leaves of Amanda and Duda cultivars with higher irrigation levels was similar to that observed in eggplant (Solanum melongena L.) (Kirnak et al. 2001) and cotton (Gossypium hirsutum) (Massacci et al. 2008). Low soil moisture values caused stomate closure and enzyme deactivation with a reduction in the concentration of this compound (Lawlor and Cornic 2002, Lawson et al. 2003).

Leaf temperatures of Amanda (Figure 3a) and Duda (Figure 3b) cultivars were 3.3 and $2.9^{\circ} \mathrm{C}$ above ambient temperature. This is significant because water availability, light, and temperature variability are the main limitations to plant development and growth (Chaerle et al. 2007). Plants exposed to high temperatures in dry conditions have lower photosynthetic activity (Rykaczewska 2015). The decrease in leaftemperature of sweet potato cultivars was more evident with increasing soil moisture, equivalent to an irrigation depth of 275 and $310 \mathrm{~mm}$ for the Amanda and Duda, respectively. Therefore, increasing and decreasing leaf temperature was proportional to water irrigation applied. Effective transpiration control and faster water movement in plants at high temperatures involves a cooling system, which protects metabolic processes (Sermons et al. 2012). The decrease in stomatal conductance has been associated with increasing leaf temperature under limited water availability conditions (Blonquist et al. 2009). However, the decrease in water absorption closes the stomata, thus reducing transpiration and increasing leaf temperature (Blonquist et al. 2009). This response provides an effective transpiration control by decreasing leaf temperature with increasing water depths.

\section{CONCLUSIONS}

Irrigation depths determined the growth and development of Amanda and Duda sweet potato cultivars. Reductions in plant growth are due to water stress limiting stomatal conductance, transpiration, leaf growth (LAI), and total chlorophyll concentration proportional to the soil moisture conditions. The functional relationship between plant morphophysiological parameters and growth are vital to optimizing irrigation management in different growth stages, which could increase carbohydrate storage and yields of sweet potato roots.

\section{ACKNOWLEDGMENTS}

We thank Conselho Nacional de Desenvolvimento Científico e Tecnológico (CNPq) and Coordenação de Aperfeiçoamento de Pessoal de Nível Superior (CAPES). Dr. Phillip Villani revised and corrected the English language in this manuscript.

\section{REFERENCES}

ABDEL CG. 2014. Leaf water relation of four radish (Raphanus sativus L. var. sativus) cultivars grown in controlled cabinets under varying temperatures and irrigation levels. Int J Agric Policy Res 2: 421-443.

ALLEN RG, PEREIRA LS, RAES D AND SMITH M. 2006. Evapotranspiración del cultivo Guías para la determinación de los requerimientos de agua de los cultivos. Estudio FAO Riego y Drenaje 56, United Nations FAO, Rome

ANGELI KP, DELAZARI FT, NICK C, FERREIRA MG AND SILVA, DJH. 2016. Yield components and water use efficiency in coriander under irrigation and nitrogen fertilization. Rev Bras Eng Agric Ambient 20: 415-420.

BERGANTIN RV, YAMAUCHI A, PARDALES JR AND BOLATETE DM. 2004. Screening cassava genotypes for resistance to water deficit during crop establishment. Philipp J Crop Sci 29: 29-39.

BLONQUIST JM, NORMAN JM AND BUGBEE B. 2009. Automated measurement of canopy stomatal conductance based on infrared temperature. Agric For Meteorol 149: 2183-2197. 
CALIMAN FRB, SILVA DJH, STRINGHETA PC, FONTES PCR, MOREIRA GR AND MANTOVANI EC. 2010. Quality of tomatoes grown under a protected environment and field conditions. Idesia 28: 75-82.

CHAERLE L, LEINONEN I, JONES HG AND VAN DER STRAETEN D. 2007. Monitoring and screening plant populations with combined thermal and chlorophyll fluorescence imaging. J Exp Bot 58: 773-784.

CHAVES MM, FLEXAS J AND PINHEIRO C. 2009. Photosynthesis under drought and salt stress: regulation mechanisms from whole plant to cell. Ann Bot 103: 551560.

DOUPIS G, BERTAKI M, PSARRAS G, KASAPAKIS I AND CHARTZOULAKIS K. 2013. Water relations, physiological behavior and antioxidant defence mechanism of olive plants subjected to different irrigation regimes. Sci Hortic 153: 150-156.

DUVERNAY WH, CHINN MS AND YENCHO GC. 2013. Hydrolysis and fermentation of sweet potatoes for production of fermentable sugars and ethanol. Ind Crops Prod 42: 527-537.

EL-SHARKAWY MA AND DE TAFUR SM. 2010. Comparative photosynthesis, growth, productivity, and nutrient use efficiency among tall-and short-stemmed rainfed cassava cultivars. Photosynthetica 48: 173-188.

FAROOQ M, WAHID N, FUJITA D AND BASRA S. 2009. Effects of drought stress on growth and yield of barley. Agron Sustain Dev 25: 145-149.

FLEXAS J ET AL. 2009. Photosynthesis limitations during water stress acclimation and recovery in the droughtadapted Vitis hybrid Richter-110 ( $\mathrm{V}$. berlandieri $\mathrm{x} V$. rupestris). J Exp Bot 60: 2361-2377.

GAJANAYAKE B, REDDY KR, SHANKLE MW AND ARANCIBIA RA. 2014. Growth, developmental, and physiological responses of two sweetpotato (Ipomoea batatas (L.) Lam.) cultivars to early season soil moisture deficit. Sci Hortic 168: 218-228.

GHOLAMI M, RAHEMI M, KHOLDEBARIN B AND RASTEGAR S. 2012 Biochemical responses in leaves of four fig cultivars subjected to water stress and recovery. Sci Hortic 148: 109-117.

GONÇALVES ER, FERREIRA VM, SILVA JV, ENDRES L, BARBOSA TP AND DUARTE WG. 2010. Gas exchange and chlorophyll a fluorescence of sugarcane varieties submitted to water stress. Rev Bras Eng Agric Ambient 14: 378-386.

IERNA A AND MAUROMICALE G. 2012. Tuber yield and irrigation water productivity in early potatoes as affected by irrigation regime. Agric Water Manag 115: 276-284.

JALEEL CA, MANIVANNAN P, WAHID A, MUHAMMAD F, HAMEED JALJ, RAMAMURTHY S AND RAJARAM PV. 2009. Drought stress in plants: A review on morphological characteristics and pigments composition. Int J Agric Biol 11: 100-105.

JANGPROMMA N, SONGSRI P, THAMMASIRIRAK S AND JAISIL P. 2010. Rapid assessment of chlorophyll in content in sugarcane using a SPAD chlorophyll meter across different water stress conditions. Asian J Plant Sci 9: 368-374.

KIRNAK H, KAYA C, HIGGS D AND GERCEK S. 2001. A long-term experiment to study the role of mulches in the physiology and macro-nutrition of strawberry grown under water stress. Crop Pasture Sci 52: 937-943.

KULKARNI M AND PHALKE S. 2009. Evaluating variability of root size system and its constitutive traits in hot pepper (Capsicum annum L.) under water stress. Sci Hortic 120: 159-166.

LAWLOR DW AND CORNIC G. 2002. Photosynthetic carbon assimilation and associated metabolism in relation to water deficits in higer plantas. Plant, Cell Environ 44:275-294.

LAWSON T, OXBOROUGH K, MORISON JIL AND BAKER NR. 2003. The responses of guard and mesophyll cell photosynthesis to $\mathrm{CO} 2, \mathrm{O} 2$, light, and water stress in a range of species are similar. J Exp Bot 54: 1743-1752.

LEE W, CHEN I, CHANG C AND YANG S. 2012. Bioethanol production from sweet potato by co-immobilization of saccharolytic molds and Saccharomyces cerevisiae. Renew Energy 39: 216-222.

LIU F AND STÜTZEL H. 2002. Leaf water relations of vegetable amaranth (Amaranthus spp.) in response to soil drying. Eur J Agron 16: 137-150.

LIU F AND STÜTZEL H. 2004. Biomass partitioning, specific leaf area, and water use efficiency of vegetable amaranth (Amaranthus spp.) in response to drought stress. Sci Hortic 102: 15-27.

LOPES AC, VIANA AES, MATSOMOTO SN, CARDOSO JÚNIOR NS AND JOSÉ ARS. 2010. Water management and harvest time on cassava cv coqueiro in Planalto de Conquista, BA. Ciênc Agrotec 34: 579-587.

MACHADO EC, SCHMIDT PT, LÁZARO C AND VASCONCELOS R. 2005. Respostas da fotossíntese de três espécies de citros a fatores ambientais. Pesqui Agropecu Bras 40: 1161-1170.

MANTOVANI EC, DELAZARI FT, DIAS LE, ASSIS IR, VIEIRA GHS AND LANDIM F. 2013. Yield and water use efficiency for two sweet potato cultivars depending on irrigation depths. Hortic Bras 31: 602-606.

MASSACCI A, NABIEV SM, PIETROSANTI L, NEMATOV SK, CHERNIKOVA TN, THOR K AND LEIPNER J. 2008. Response of the photosynthetic apparatus of cotton (Gossypium hirsutum) to the onset of drought stress under field conditions studied by gas-exchange analysis and chlorophyll fluorescence imaging. Plant Physiol Biochem 46: 189-195. 
MONTEFUSCO A, DURANTE M, GRASSI S, PIRO G, DALESSANDREO G AND LENUCCI MS. 2014. Assessment of sweet potato (Ipomoea batatas (L.) Lam.) for bioethanol production in southern Italy. Plant Biosyst 148: 1117-1126.

NOGUEIRA R, MORALES J AND BURITY H. 2000. Curso diário e sazonal das trocas gasosas e do potencial hídrico foliar em aceloreiras. Pesqui Agropecuária Bras 35: 13311342.

POSADA JM, SIEVÄNEN R, MESSIER C, PERTTUNEN J, NIKINMAA E AND LECHOWICZ MJ. 2012. Contributions of leaf photosynthetic capacity, leaf angle and self-shading to the maximization of net photosynthesis in Acer saccharum: a modelling assessment. Ann Bot 110: 731-741.

R DEVELOPMENT CORE TEAM. 2014. R: A Language and Environment for Statistical Computing, R Foundation for Statistical Computing, Vienna, Austria.

RIBEIROAC, GUIMARÃES PTG AND ALVAREZ VH. 1999. Recomendações para o uso de corretivos e fertilizantes em Minas Gerais, $5^{\text {th }}$ ed., Soc Bras Ciênc Solo, Viçosa.

RYKACZEWSKA K. 2015. The effect of high temperature occurring in subsequent stages of plant development on potato yield and tuber physiological defects. Am J Potato Res 92: 339-349.

SANTOS R AND CARLESSO R. 1998. Déficit hídrico e os processos morfológico e fisiolólogico das plantas. Rev Bras Eng Agric Ambient 2: 287-294.

SATO F, YOSHIOKA H, FUJIWARA T, HIGASHIO H, URAGAMI A AND TOKUDA S. 2004. Physiological responses of cabbage plug seedlings to water stress during low-temperature storage in darkness. Sci Hortic 101: 349357.

SCHOLANDER PF, BRADSTREET ED, HEMMINGSEN EA AND HAMMEL HT. 1965. Sap pressure in vascular plants: Negative hydrostatic pressure can be measured in plants. Science 148: 339-346.

SERMONS SM, SEVERSIKE TM, SINCLAIR TR AND RUFTY TW. 2012. Temperature influences the ability of tall fescue to control transpiration in response to atmospheric vapour pressure deficit. Funct Plant Biol 39: 979-986.

SIDDIQUE MRB, HAMID A AND ISLAM MS. 2000. Drought stress effects on water relations of wheat. Bot Bull Acad Sin 41: 35-39.

SINGH SK AND REDDY KR. 2011. Regulation of photosynthesis, fluorescence, stomatal conductance and water-use efficiency of cowpea (Vigna unguiculata [L.] Walp.) under drought. J Photochem Photobiol B Biol 105: 40-50.

SONGSRI P, JOGLOY S, KESMALA T, VORASOOT N, AKKASAENG C, PATANOTHAI A AND HOLBROOK CC. 2008. Response of reproductive characters of drought resistant peanut genotypes to drought. Asian J Plant Sci 7: 427-439.

TESTI L, GOLDHAMER DA, INIESTA F AND SALINAS M. 2008. Crop water stress index is a sensitive water stress indicator in pistachio trees. Irrig Sci 26: 395-405.

WARREN CR. 2008. Soil water deficits decrease the internal conductance to $\mathrm{CO}_{2}$ transfer but atmospheric water deficits do not. J Exp Bot 59: 327-334.

WILLIAMS PH AND ARAÚJO MB. 2002. Apples, oranges, and probabilities: Integrating multiple factors into biodiversity conservation with consistency. Environ Model Assess 7: 139-151.

YOOYONGWECH S, THEERAWITAYA C, SAMPHUMPHUANG T AND CHA-UM S. 2013. Waterdeficit tolerant identification in sweet potato genotypes (Ipomoea batatas (L.) Lam.) in vegetative developmental stage using multivariate physiological indices. Sci Hortic 162: $242-251$. 